\title{
Spatial variability and human disturbance in shallow subtidal hard substrate assemblages: a regional approach
}

\author{
Simonetta Fraschetti ${ }^{1, *}$, C. Nike Bianchi ${ }^{2}$, Antonio Terlizzi ${ }^{1}$, Giovanni Fanelli ${ }^{3}$, \\ Carla Morri ${ }^{4}$, Ferdinando Boero ${ }^{1}$ \\ ${ }^{1}$ Dipartimento di Biologia, Stazione di Biologia Marina di Porto Cesareo, CoNISMa, Università di Lecce, 73100 Lecce, Italy \\ ${ }^{2}$ Marine Environmental Research Centre, ENEA Santa Teresa, PO Box 316, 19100 La Spezia, Italy \\ ${ }^{3}$ Istituto Sperimentale Talassografico del CNR ‘A. Cerruti', Via Roma 4, 74100 Taranto, Italy \\ ${ }^{4}$ DipTeRis, Dipartimento per lo studio del Territorio e delle sue Risorse, Università di Genova, Corso Europa 26, \\ 16132 Genoa, Italy
}

\begin{abstract}
Quantitative information about spatial patterns in subtidal hard substrate assemblages is scant. Such information is necessary to understand the responses to anthropogenic disturbances in these habitats. Along the coast of Apulia (Southern Italy), the collection of the European date mussel Lithophaga lithophaga is a strong source of disturbance: harvesting is carried out by demolition of the rocky substrate and causes epibiota disappearance. A hierarchical sampling design was used to quantify the spatial variability of subtidal epibenthic assemblages and the extent of rock damage due to L. lithophaga harvesting along $360 \mathrm{~km}$ of rocky coasts in Apulia. The surveyed coast was divided into 8 adjacent sectors, and replicate samples were taken by visual inspection at each of the 3 sites nested in each sector. Multivariate analyses indicated that assemblages differed consistently with spatial scale, variability being higher at the largest scale. However, variability among sites within each sector was also detected. Patchiness (i.e., average similarity among quadrats) was consistent among sectors. Some species were identified as 'important' in characterising and/or differentiating sectors. The pattern of distribution of these species as well as total cover and number of species were analysed by analysis of variance. Results recorded a considerable source of variation at site level. Damage by $L$. lithophaga fishing was shown to be extremely widespread. A humped relationship between patchiness and disturbances by L. lithophaga fisheries was obtained. In particular, patchiness at a small scale was highest at 'intermediate' levels of damage, because disturbance produces patches of different size and/or age, leading to 'mosaic' landscapes of epibenthic assemblages.
\end{abstract}

KEY WORDS: Subtidal assemblage - Spatial scale - Human disturbance - Rocky substrate . Lithophaga lithophaga $\cdot$ Mediterranean Sea

\section{INTRODUCTION}

The change in environmental conditions and the impact of human activities can be the main causes of landscape heterogeneity at different scales, from local patchiness to variation along climatic gradients (Levin

\footnotetext{
*E-mail: sfrasca@ilenic.unile.it
}

1992, Tilman \& Kareiva 1997). Linkage across multiple scales is increasingly considered by ecologists (Peterson \& Parker 1998). The proposal of macroecology (Brown 1995, Maurer 1999) as a way to reconcile biogeography and ecology mainly focuses on terrestrial habitats (Boero 1999). Its rationale should be equally applicable to marine environments. The complementary vision of landscape ecology is again primarily interested in terrestrial environment (Forman \& Godron 
1986, Farina 1998), but the application of these concepts to the sea is timely (Cocito et al. 1991, Garrabou et al. 1998a, Smith \& Witman 1999).

The most obvious distribution pattern of hard substrate marine communities is vertical zonation, which is often explained with the variation of environmental factors such as light (Pérès 1982) or water movement (Riedl 1971). Attention towards abiotic factors characterised the continental-European approach, whereas British and American ecologists, often dealing with intertidal communities only (Connolly \& Roughgarden 1999), mainly invoked biotic interactions to explain community patterns. Following Dunson \& Travis (1991), Barry \& Dayton (1991) re-appraised the ecological importance of physical factors in the organisation of marine communities. Since competition operates at a more local scale than climate, consideration of scale is a way to reconcile the 2 approaches.

The large-scale distribution of subtidal marine biota mostly concerns biogeography and has rarely been linked to ecological features, especially in the case of rocky substrates. Many modern studies of ecological patterns concentrate on small-scale structuring processes, such as competition and predation, or local heterogeneity within habitat (Chapman 1994, Thompson et al. 1996, Benedetti-Cecchi et al. 1999). Whilst the need to detect community variability at different spatial scales is widely recognised (Butler \& Chesson 1990, Hewitt et al. 1998), few studies of marine hard substrata have explicitly embraced a hierarchy of spatial scales (Glasby 1999). Most information derives from the intertidal (Paine et al. 1985, Underwood \& Chapman 1996, 1998a,b, Benedetti-Cecchi et al. 2000); but, in the constantly submerged subtidal, the influence of gradients of spatial scales larger than tens of metres on biodiversity is a growing field of interest (Kennelly \& Underwood 1993, Chapman et al. 1995, Cornell \& Karlson 1996, Roberts 1996, Guichard \& Bourget 1998, Hughes et al. 1999, Smith \& Witman 1999). The scant information available on the subtidal means that possible linkages between large- and small-scale processes, in areas from patches to landscapes, are poorly understood. Probably, the paucity of data available on this topic is also linked to the fact that large-scale research in the subtidal is expensive and severely time-limited by logistics.

Subtidal rocky substrates of the Mediterranean Sea are intensively used by humans for a number of activities, which range from seafood collection to diving tourism (Garrabou et al. 1998b). A high percentage of the coast of Apulia (South-Eastern Italy, between the Southern Adriatic and Ionian Seas) is of great significance in social-economic terms for fisheries and tourism. The coast of Apulia is several hundreds of $\mathrm{km}$ long (Fig. 1) and is characterised by long rocky stretches, separated by sandy beaches. The geographic position and variety of the coast make the subtidal communities of Apulia extremely varied in terms of species composition and biogeographic affinities (Bedulli et al. 1986, Damiani et al. 1988).

Two surveys carried out in the last 10 yr (Fanelli et al. 1994) revealed that Apulian rocky subtidal habitats are continuously subjected to the intensive human predation on the European date mussel Lithophaga lithophaga. Date mussel collection requires breaking of rocks to expose the molluscs, causing the destruction of the epibiota (Russo \& Cicogna 1992, Fanelli et al. 1994). This leads to either complete desertification or 'mosaic' landscapes of epibenthic assemblages. The importance of this phenomenon was remarked on by Naylor (1995), while Dayton et al. (1995) and Hall (1999) cited it as a prime example of fishery disturbance on subtidal hard substrates.

During the spring of 1997, we surveyed the rocky coasts of Apulia, analysing the subtidal sessile epibiota across spatial scales ranging from metres to hundreds of $\mathrm{km}$. A hierarchical sampling design provided a framework for quantifying the variation among samples due to each spatial scale (Underwood 1997). We chose to sample subvertical rocky walls at about $5 \mathrm{~m}$ depth, usually characterised by more or less diverse algal assemblages (Pérès 1982).

The present paper describes tests of hypotheses about spatial distribution of such epibenthic assemblages. Disturbance, however, plays a major role in creating different patterns of change from place to place (Connell \& Sousa 1983, Airoldi 1998). Thus, in addition, the study evaluates the extent of rock damage due to L. lithophaga fisheries and how this form of disturbance could play a role in influencing the pattern of natural variability of epibenthic assemblages.

Most published studies focus on the spatial variation of mean abundance of either individual species, sets of interacting species, or so-called functional groups of species. Here the spatial variability has been evaluated considering the pattern of distribution of species richness, total cover, community structure (i.e., qualiquantitative species composition), and 'important' taxa (i.e., those whose relative cover characterises and/or differentiates assemblages).

\section{METHODS}

Study sites and sampling. From 12 to 23 May 1997, a survey from Peschici $\left(41^{\circ} 57^{\prime} \mathrm{N}, 16^{\circ} 00^{\prime} \mathrm{E}\right)$ to Taranto $\left(40^{\circ} 24^{\prime} \mathrm{N}, 17^{\circ} 12^{\prime} \mathrm{E}\right)$, Southern Italy, was carried out, covering most of the Apulian coast. The surveyed area was divided into 650 sections of $1 \mathrm{~km}$ each, and only the 360 sections with rocky substrates were consid- 


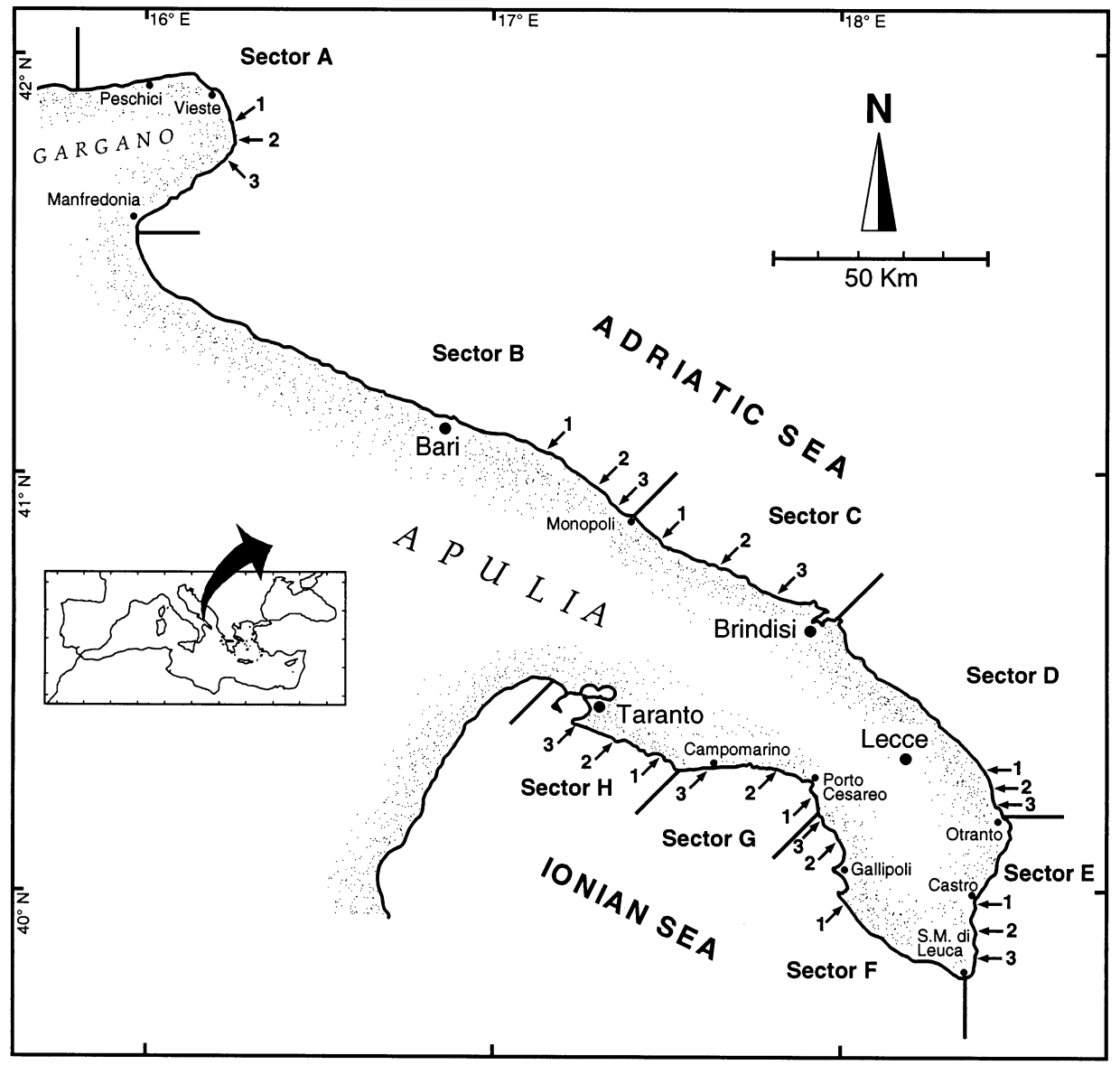

Fig. 1. Surveyed coast and its positioning in the Mediterranean region. The sampling sites (1 to 3), randomly selected among rocky substrate sections within each of the 8 sectors (A to $H$ ), are shown

ered. These were grouped into 8 adjacent sectors, having unequal total length because of different proportions of sandy and rocky bottoms, but all including 45 rocky sections. In each sector, 3 sampling sites were randomly selected out of the 45 sections (Fig. 1). Subtidal sessile epibiota was investigated by visual estimation of 3 random quadrats on sub-vertical rocky surfaces at about $5 \mathrm{~m}$ depth. Thus, 3 spatial scales were considered: small (2 to $15 \mathrm{~m})$, variation between quadrats at each site; intermediate ( 3 to $21 \mathrm{~km}$ ), variation between sites within sectors; and broad (45 to $500 \mathrm{~km}$ ), variation between sectors.

A single team of 5 researchers performed sampling operations. Sampling quadrats were $1 \mathrm{~m}^{2}$ divided into 25 equal squares. The percent substrate cover by conspicuous organisms was quantified by giving each individual taxon a score ranking from 0 to 4 in each smaller square, and then adding up scores for all the smaller squares where the taxon was present. Final values were expressed as percentages. Organisms filling less than $1 / 4$ square were given an arbitrary value of 0.5 (Dethier et al. 1993). Conspicuous organisms were directly recognised in the field; specimens were collected for later identification only when in doubt.

At each site, the presence of date mussels (as living specimens or as empty galleries) was recorded. The impact of Lithophaga lithophaga fisheries was assessed in 5 randomly selected surfaces of $10 \times 2 \mathrm{~m}$. Rock damage measurements were obtained by considering the size and frequency of disturbed patches (e.g., evident breaks in the rocks). For each sampling surface a score ranging from 0 to 7 was assigned following the damage evaluation categories reported in Fanelli et al. (1994). Observed values were then divided by 7 to relate the observed damage to the maximum possible damage, obtaining a weighted index of rock damage $\left(D_{\mathrm{w}}\right)$ ranging between 0 (absence of damage) and 1 (complete desertification).

Statistical analysis. Spatial patterns of total cover and species richness were examined by 2-way ANOVA (GMAV5, University of Sidney). Sectors were 
considered as random factors, sites were randomly nested in sectors, and quadrats provided 3 replicates. The homogeneity of variance was tested by Cochran's test $(C)$ (Underwood 1997).

Analysis of similarities (ANOSIM, Clarke 1993) was used to compare community structure within and among sectors, under the hypothesis that assemblages differ at the broad spatial scale (among sectors) but not at the smaller spatial scale within each sector (among sites). Comparisons were based on Bray-Curtis similarity values $\left(S_{\mathrm{BC}}\right)$ (Bray \& Curtis 1957) calculated on all taxa within each quadrat (PRIMER, Plymouth Marine Laboratory, Clarke 1993). Data were fourth root transformed to arrange all organisms in the same range of abundance.

To test the hypothesis of higher similarities among sites within the same sector than among sites from different sectors, the mean dissimilarities among sites in each sector $\left(1-S_{\mathrm{BC}}\right)$ were compared to the average dissimilarity (and 95\% confidence limits) among the remaining sectors. Differences among sectors, as well as among sites within each sector, were represented by non-metric multidimensional scaling ordinations (MDS), considering site centroids (the mean cover values of each taxon in the 3 replicate quadrats of each site) and sector centroids (the mean cover values of each taxon in the 3 sites of each sector). Stress values were shown for each MDS plot to indicate the goodness of representation of differences among samples.

The average dissimilarity within a site was used to measure variability among replicate quadrats. ANOVA was performed to test the hypothesis that variability within sites (i.e., community patchiness) differed among sectors. Sectors were random factors, and sites provided 3 replicate readings.

SIMPER (Clarke 1993) was used to identify 'important' taxa. These had covers that contributed more than $10 \%$ to similarity among sites within each sector and/or that accounted for at least $5 \%$ of the average dissimilarity among sectors. The spatial patterns of these important taxa were examined using ANOVA. In some cases, the variances of species cover did not meet the assumption of homogeneity ( $p>0.05)$. Nevertheless, since ANOVA is considered sufficiently robust to the departures from the assumption, the analyses were still interpreted with the more conservative probability level of 0.01 (Underwood 1997).

Spatial patterns of rock damage were examined using 2-way ANOVA to test for differences among and within sectors. To test for relationship between community patchiness and rock damage, values of dissimilarity within sites $\left(1-S_{\mathrm{BC}}\right)$ were plotted against the values of $D_{\mathrm{w}}$ averaged for each site. This relationship was described by polynomial regression.

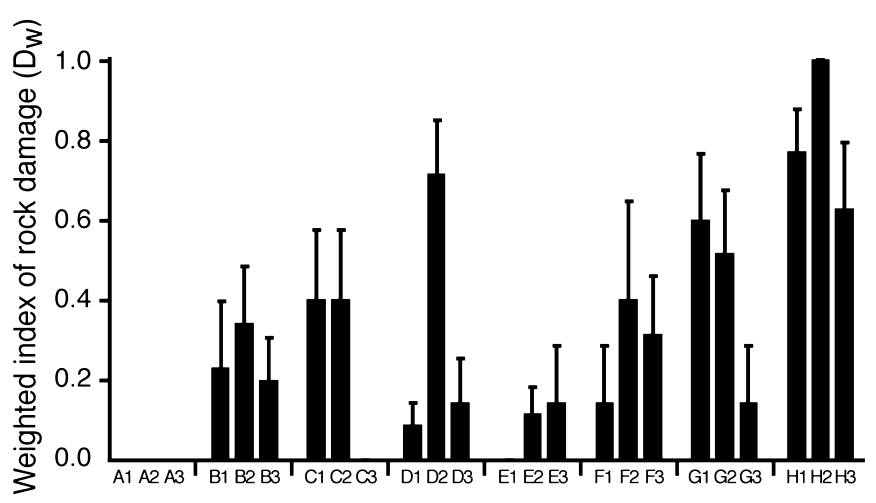

Fig. 2. Spatial pattern of weighted index of rock damage $\left(D_{\mathrm{w}}\right)$ (mean $\pm \mathrm{SE}, \mathrm{n}=5$ )

\section{RESULTS}

\section{Disturbance by date mussel fisheries}

The 3 sites of Sector A (Gargano peninsula) were unaffected by date mussel fisheries, possibly because substrate or other conditions are not suitable for abundant date mussel settlement. Rock damage due to Lithophaga lithophaga fisheries was widespread in most of the remaining 21 sites suitable for date mussel settlement (mean $D_{\mathrm{w}}=0.35, \mathrm{SE}=0.06, \mathrm{n}=21$ ). Significant differences were detected among sectors (2-way ANOVA, $\left.F_{7,16}=3.51, \mathrm{p}<0.05\right)$. Sector $H$ showed the highest values of rock damage (mean $D_{\mathrm{w}}=0.80 \mathrm{SE}=$ $0.11, \mathrm{n}=3$ ), whilst the lowest damage was recorded in Sector E (mean $D_{\mathrm{w}}=0.09 \mathrm{SE}=0.04, \mathrm{n}=3$ ) (Fig. 2). Rock damage varied significantly also among sites within sectors $\left(F_{16,48}=2.26, \mathrm{p}<0.05\right)$.

\section{Substrate cover}

The total amount of substrate covered by algae and sessile animals ranged from 12 to $96 \%$, with a global average value of $52.8 \%(\mathrm{SE}=2.2, \mathrm{n}=72)$. Cover did not vary significantly among sectors (2-way ANOVA, $\left.F_{7,16}=1.25, \mathrm{p}>0.05\right)$. Significant differences were found among sites within sectors $\left(F_{16,48}=3.29\right.$, p < 0.001).

\section{Species richness}

A total of 91 taxa were recognised in the field (Table 1). Almost all taxa were identified to species level, except for a few groups in which a consistent species distinction in all quadrats turned out to be impossible. Later examination of voucher specimens meant that the identified group 'Encrusting calcified 
Table 1. Taxonomic list of the species (or species groups) recorded

\begin{tabular}{|c|c|}
\hline Rhodophyceae & Porifera (continued) \\
\hline Filamentous red algae & Haliclona sp. \\
\hline Encrusting calcified red algae & Hemimycale columella (Bowerbank) \\
\hline Amphiroa sp. & Ircinia oros (Schmidt) \\
\hline Corallina elongata Ellis et Solander & Ircinia variabilis (Schmidt) \\
\hline Haliptilon virgatum (Zanardini) Garbary et Johansen & Peraplysilla spinifera Schulze \\
\hline Dudresnaya verticillata (Withering) Le Jolis & Petrosia ficiformis (Poiret) \\
\hline Jania rubens (L.) Lamouroux & Phorbas fictitius (Bowerbank) \\
\hline Laurencia obtusa (Hudson) Lamouroux & Phorbas tenacior (Topsent) \\
\hline Liagora viscida (Forsskål) C. Agardh & Tethya aurantium (Pallas) \\
\hline Peyssonnelia dubyi Crouan et Crouan & Hydrozoa \\
\hline Peyssonnelia squamaria (Gmelin) Decaisne & Hydroids \\
\hline Scinaia furcellata (Turner) J. Agardh & 11yuroics \\
\hline Sphaerococcus coronopifolius Stackhouse & Anthozoa \\
\hline Phaeophyceae & Aiptasia mutabilis (Gravenhorst) \\
\hline Filamentous brown algae & Anemonia viridis (Forsskål) \\
\hline $\begin{array}{l}\text { Filamentous brown algae } \\
\text { Colpomenia sinuosa (Mertens) Derbs et Solier }\end{array}$ & Balanophyllia europaea (Risso) \\
\hline $\begin{array}{l}\text { Colpomenia sinuosa (Mertens) Derbs et Solıer } \\
\text { Cystoseira compressa (Esper) Gerloff et Nizamuddin }\end{array}$ & Cereus pedunculatus (Pennant) \\
\hline $\begin{array}{l}\text { Cystoseira compressa (Esper) Gerloft et Nizamuddin } \\
\text { Dictyopteris polypodioides (De Candolle) Lamouroux }\end{array}$ & Cladocora caespitosa (L.) \\
\hline $\begin{array}{l}\text { Dictyopteris polypodioides (De Candolle) Lamouroux } \\
\text { Dictyota dichotoma (Hudson) Lamouroux }\end{array}$ & Corynactis viridis Allman \\
\hline $\begin{array}{l}\text { Dictyota dichotoma (Hudson) Lamouroux } \\
\text { Dictyota spiralis Montagne }\end{array}$ & Maasella edwardsi Lacaze-Duthiers \\
\hline $\begin{array}{l}\text { Dictyota spiralis Montagne } \\
\text { Stypocaulon scoparium (L.) Kützing }\end{array}$ & Parazoanthus axinellae (Schmidt) \\
\hline Padina pavonica (L.) Thivy & Polychaeta \\
\hline Pseudolithoderma adriaticum (Hauck) Verlaque & Serpulids \\
\hline Sargassum vulgare C. Agardh & Bivalvia \\
\hline Zanardinia prototypus (Nardo) Nardo & Mytilus galloprovincialis Lamarck \\
\hline Chlorophyceae & Ostrea edulis L. \\
\hline Filamentous green algae & Spondylus gaederopous L. \\
\hline Acetabularia acetabulum (L.) Silva & Gastropoda \\
\hline Anadyomene stellata (Wulfen) C. Agardh & Serpulorbis arenaria (L.) \\
\hline Cladophora sp. & Vermetus triquetrus Ant. Bivona \\
\hline Codium bursa (L.) C. Agardh & Cirripedia \\
\hline Codium effusum (Rafinesque) Delle Chiaje & Balanus perforatus Bruguière \\
\hline $\begin{array}{l}\text { Codium vermilara (Olivi) Delle Chiaje } \\
\text { Flabellia petiolata (Turra) Nizamuddin }\end{array}$ & Bryozoa \\
\hline Halimeda tuna (Ellis et Solander) Lamouroux & Calpensia nobilis (Esper) \\
\hline Palmophyllum crassum (Naccari) Rabenhorst & Frondipora verrucosa (Lamouroux) \\
\hline Ulva laetevirens C. Agardh & Myriapora truncata (Pallas) \\
\hline Valonia macrophysa Kützing & Reptadeonella violacea Johnston \\
\hline Porifera & Schizoporella longirostris Hincks \\
\hline Acanthella acuta Schmidt & Scrupocellaria reptans (L.) \\
\hline Aplysina aerophoba Schmidt & Sertella septentrionalis Harmer \\
\hline Axinella cannabina (Esper) & Ascidiacea \\
\hline Axinella polypoides Schmidt & Aplidium conicum Olivi \\
\hline Chondrilla nucula Schmidt & Aplidium proliferum (Milne-Edwards) \\
\hline Chondrosia reniformis Nardo & Botryllus schlosseri (Pallas) \\
\hline Cliona celata Grant & Cystodites dellechiajei (Della Valle) \\
\hline Cliona copiosa Sarà & Didemnum maculosum (Milne-Edwards) \\
\hline Cliona rhodensis Rutzler et Bromley & Diplosoma listerianum (Milne-Edwards) \\
\hline Cliona viridis (Schmidt) & Halocynthia papillosa (L.) \\
\hline Crambe crambe (Schmidt) & Microcosmus sp. \\
\hline Guancha lacunosa (Johnston) & Perophora viridis Verrill \\
\hline Halichondria panicea (Pallas) & Polysyncraton lacazei (Giard) \\
\hline
\end{tabular}

red algae' included at least the species Lithophyllum frondosum (Dufour) Furnari, Cormaci et Alongi, Lithophyllum incrustans Philippi, Mesophyllum alternans (Foslie) Cabioch \& Mendoza and Peyssonnelia polymorpha (Zanardini) Schmitz. Similarly, Aglaophenia tubiformis Marktanner-Turneretscher, Eudendrium capillare Alder, Eudendrium ramosum (L.), Plumularia sp., Sertularella ellisi (Deshayes et Milne-Edwards), Synthecium evansi (Ellis et Solander) and Ventromma halecioides (Alder) were recognised within the group 


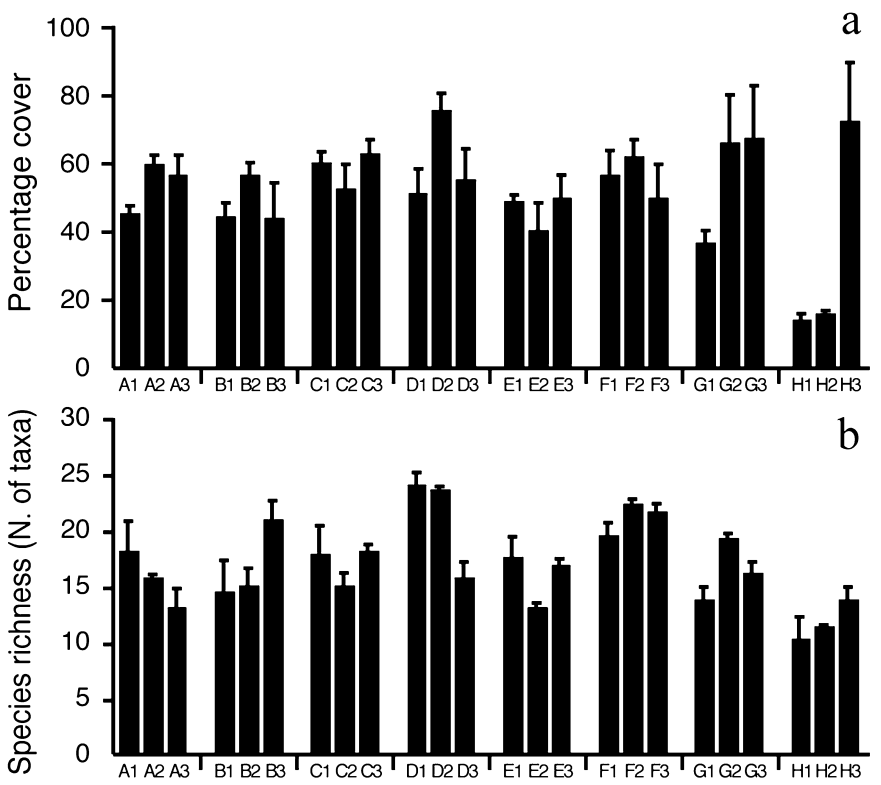

Fig. 3. Spatial pattern of (a) percentage substratum cover (mean $\pm \mathrm{SE}, \mathrm{n}=3$ ) and (b) species richness (mean number of taxa $\pm \mathrm{SE}, \mathrm{n}=3$ )

'Hydroids', and Hydroides pseudouncinatus Zibrowius, Pomatoceros triqueter (L.), Protula tubularia (Montagu), Serpula vermicularis L. and Vermiliopsis striaticeps (Grube) within the 'Serpulids'. These identifications bring the number of species recorded to (at least) 102. No attempt to identify filamentous algae was made.

The number of taxa per quadrat ranged from 7 to 26 , with an overall mean of $16.8(\mathrm{SE}=0.5, \mathrm{n}=72)$. Species richness varied both among (2-way ANOVA, $F_{7,16}=$ $3.59, \mathrm{p}<0.05)$ and within sectors $\left(F_{16,48}=3.36, \mathrm{p}<\right.$ 0.001). The richest site was D1, the poorest H1 (Fig. 3b).

\section{Community structure}

The null hypothesis that community structure was similar at all sectors was rejected (ANOSIM, R $=0.58$, $p<0.001$ ). This is also shown by the ordination of sector centroids by MDS, representing differences among assemblages from sector to sector when variability among sites and among quadrats is ignored. All sectors are well separated from each other, except for Sectors F and G, which are characterised by an overlap in similarity (Fig. 4a). A geographical trend is also singled out, the highest distance being between Sector A (Adriatic Sea) and Sector H (Ionian Sea), passing through the sectors between them.

As observed for sectors, the null hypothesis that community structure was similar at all sites was
Table 2. Significant differences in community structure (ANOSIM) among sites in each sector $(\mathrm{n}=3$ quadrats per site; $\left.{ }^{*} \mathrm{p}<0.05 ;{ }^{* *} \mathrm{p}<0.01\right)$

\begin{tabular}{|cc|}
\hline Sector & Significance \\
\hline A & $* *$ \\
B & $* *$ \\
C & $* *$ \\
D & $*$ \\
E & $*$ \\
F & $*$ \\
G & $*$ \\
H & $* *$ \\
\hline
\end{tabular}

Table 3. Average dissimilarity in community structure (1 $S_{\mathrm{BC}}$ ) among sites within each sector and average dissimilarity (with $95 \%$ confidence limits, CL, in parenthesis) between each sector and all the remaining ones

\begin{tabular}{|lcc|}
\hline Sector & $\begin{array}{c}\text { Dissimilarity among } \\
\text { sites within sector }\end{array}$ & $\begin{array}{c}\text { Dissimilarity with } \\
\text { remaining sectors }\end{array}$ \\
\hline A & 56.3 & $75.8(4)$ \\
B & 50.9 & $68.9(4)$ \\
C & 40.0 & $64.2(4)$ \\
D & 52.7 & $64.5(4)$ \\
E & 54.2 & $70.1(4)$ \\
F & 53.3 & $65.0(5)$ \\
G & 53.1 & $66.7(5)$ \\
H & 61.3 & $69.9(5)$ \\
\hline
\end{tabular}

rejected (ANOSIM, $\mathrm{n}=3$ quadrats per site, $\mathrm{R}=0.90$, $\mathrm{p}<0.001)$. ANOSIM performed on each sector also detected significant differences among sites (Table 2).

The MDS representation of site centroids suggested a higher variability among sites in Sectors A, F, G and $\mathrm{H}$ (Fig. 4b). However, dissimilarity among sites within each sector was always smaller than the mean dissimilarity between the same sectors and the remaining ones (Table 3).

When expressed as average dissimilarities among replicate quadrats within each site (see 'Methods'),

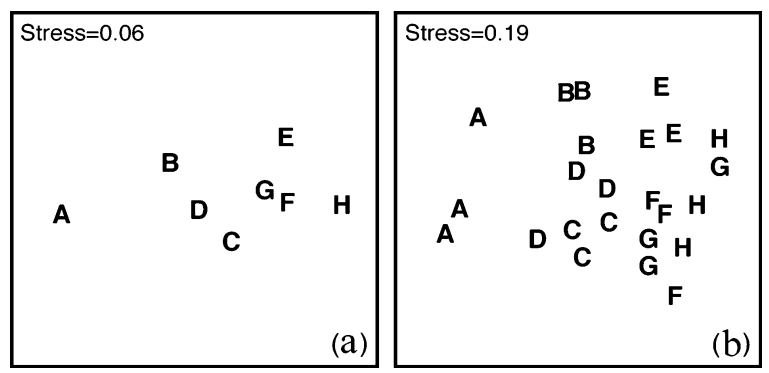

Fig. 4. Non-metric multidimensional scaling ordinations of (a) sector centroids and (b) site centroids 


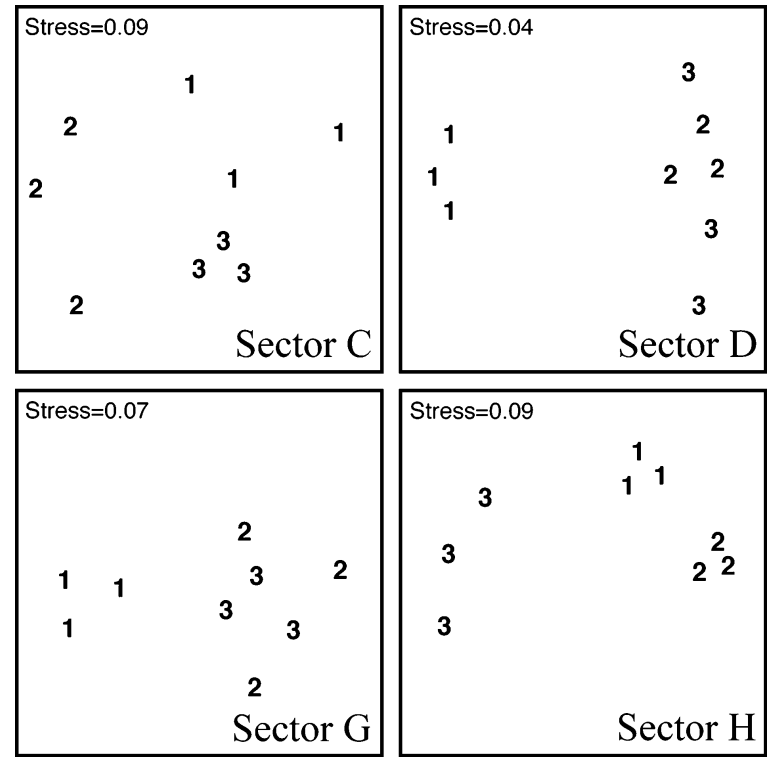

Fig. 5. Non-metric multidimensional scaling ordinations of individual quadrats in 4 selected sectors

patchiness was similar across sectors (1-way ANOVA, $\left.F_{7,16}=1.57, \mathrm{p}>0.05\right)$; but, in each sector, MDS of individual quadrats evidenced different levels of patchiness at different sites. The clearest examples of these different levels of patchiness were found in Sectors C, D, G and H (Fig. 5). Quadrats were more clearly grouped at sites with either the lowest (e.g., C3) or the highest values (e.g., H2) of $D_{\mathrm{w}}$. The possibility of a humped relationship between community patchiness and disturbance by date mussel fisheries was tested by plotting dissimilarity values calculated for each site against the corresponding $D_{\mathrm{w}}$ values and fitting the plot with a second-order polynomial. This showed that the highest level of dissimilarity within sites (i.e., highest patchiness) corresponded to intermediate levels of rock damage (Fig. 6).

\section{Important taxa}

Despite the large number of recorded taxa, SIMPER identified only 14 important taxa in characterising and/or differentiating sectors. Encrusting calcified red algae were important in all sectors, whereas the importance of the other 13 taxa varied greatly. Peyssonnelia squamaria, Chondrosia reniformis and Schizoporella longirostris were important in Sector A (Gargano Promontory). In the Southern Adriatic sectors, Cereus pedunculatus was important in Sector B, P. squamaria and Halimeda tuna in Sector C, and Calpensia nobilis in Sector D. In the Ionian sectors, filamentous brown

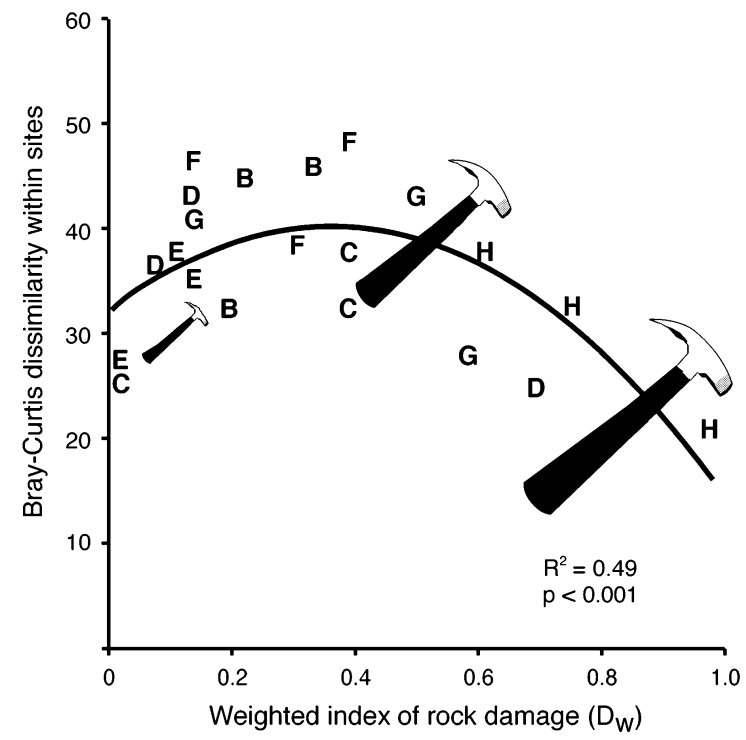

Fig. 6. Relationship between community patchiness (represented by the dissimilarity values for each site) and weighted index of rock damage $\left(D_{\mathrm{w}}\right)$. The size of the hammers is roughly proportional to the intensity of the disturbance caused by Lithophaga lithophaga fisheries

algae and Phorbas fictitus were important in Sector E, and C. nobilis in Sectors F and G. In Sector G, serpulids and Crambe crambe were also important. The important species of Sector H were Balanophyllia europaea and C. crambe (Table 4).

The cover of important taxa had different patterns along the coast (Fig. 7). Only encrusting calcified red algae Crambe crambe and Schizoporella longirostris showed significant cover variations among sectors. Almost all important taxa, apart from encrusting calcified red algae, filamentous brown algae, C. crambe, Chondrosia reniformis and Cladocora caespitosa, showed significant cover variations among sites within sectors. Cover variations both among and within sectors were found only for $S$. longirostris (Table 5).

\section{DISCUSSION}

The structure of assemblages varied with greater differences at greater observation scales. Results are also in accordance with the geographical trends of the surveyed coast and could support the hypothesis of Carlile et al. (1989) that communities differ consistently with the latitudinal gradient, probably reflecting biogeographic differences. Studies on intertidal and coral communities, however, report that neighbouring sites differed more from each other than from far apart ones (Underwood \& Chapman 1996, Hughes et al. 1999, Smith \& Witman 1999). This is likely to be 
Table 4. Important taxa, contributing to similarity among sites for each sector (characterisation of sectors) and/or dissimilarity among sectors (differentiation of sectors). Values of similarity $\geq 10 \%$ (in the first case) and of dissimilarity $\geq 5 \%$ (in the second case) are given in bold

\begin{tabular}{|c|c|c|c|c|c|c|c|c|c|c|c|c|c|c|c|c|c|}
\hline \multirow[t]{2}{*}{ Taxon } & \multirow[t]{2}{*}{ Code } & \multicolumn{8}{|c|}{$\begin{array}{l}\text { Characterization of sectors } \\
\text { Similarity values }\left(S_{\mathrm{BC}}\right)\end{array}$} & \multicolumn{8}{|c|}{$\begin{array}{c}\text { Differentiation among sectors } \\
\text { Dissimilarity values }\left(1-S_{\mathrm{BC}}\right)\end{array}$} \\
\hline & & A & $\mathrm{B}$ & $\mathrm{C}$ & $\mathrm{D}$ & $\mathrm{E}$ & $\mathrm{F}$ & G & $\mathrm{H}$ & $\mathrm{A}$ & B & $\mathrm{C}$ & $\mathrm{D}$ & $\mathrm{E}$ & $\mathrm{F}$ & G & $\mathrm{H}$ \\
\hline Encrusting calcified red algae & Ecr & 12 & 24 & 13 & 20 & 26 & 16 & 15 & 28 & 3 & 4 & 2 & 2 & 3 & 2 & 3 & 3 \\
\hline Halimeda tuna & Htu & 0 & 0 & 15 & 8 & 0 & 3 & 11 & 9 & 4 & 4 & 5 & 5 & 4 & 4 & 5 & 5 \\
\hline Peyssonnelia squamaria & Psq & 14 & 3 & 16 & 7 & 0 & 3 & 1 & 0 & 5 & 4 & 6 & 4 & 4 & 3 & 4 & 4 \\
\hline Calpensia nobilis & Cno & 0 & 2 & 1 & 10 & 1 & 15 & 15 & 4 & 3 & 3 & 3 & 4 & 3 & 5 & 4 & 4 \\
\hline Filamentous brown algae & Fib & 0 & 0 & 1 & 0 & 10 & 5 & 0 & 0 & 1 & 2 & 3 & 2 & 5 & 4 & 2 & 2 \\
\hline Dictyota dichotoma & Ddi & 2 & 0 & 11 & 5 & 6 & 6 & 1 & 4 & 3 & 3 & 4 & 3 & 3 & 3 & 3 & 4 \\
\hline Crambe crambe & $\mathrm{Ccr}$ & 5 & 0 & 2 & 3 & 4 & 5 & 11 & 15 & 2 & 3 & 3 & 3 & 3 & 3 & 3 & 3 \\
\hline Serpulids & Ser & 0 & 11 & 5 & 6 & 6 & 6 & 12 & 2 & 3 & 2 & 2 & 2 & 2 & 2 & 2 & 3 \\
\hline Phorbas fictitius & Pfi & 0 & 11 & 0 & 5 & 13 & 2 & 0 & 0 & 2 & 4 & 2 & 3 & 4 & 2 & 2 & 3 \\
\hline Chondrosia reniformis & Cre & 11 & 3 & 9 & 2 & 0 & 0 & 0 & 2 & 3 & 3 & 4 & 3 & 3 & 3 & 2 & 3 \\
\hline Schizoporella longirostris & Slo & 14 & 0 & 0 & 0 & 0 & 1 & 0 & 0 & 5 & 1 & 1 & 1 & 1 & 2 & 1 & 1 \\
\hline Cladocora caespitosa & $\mathrm{Cca}$ & 2 & 10 & 1 & 3 & 1 & 0 & 1 & 1 & 2 & 3 & 2 & 2 & 2 & 2 & 3 & 2 \\
\hline Balanophyllia europea & Beu & 0 & 1 & 0 & 2 & 0 & 3 & 7 & 14 & 2 & 2 & 2 & 2 & 2 & 3 & 3 & 3 \\
\hline Cereus pedunculatus & Cpe & 2 & 13 & 5 & 0 & 0 & 0 & 0 & 0 & 2 & 4 & 3 & 1 & 2 & 1 & 1 & 2 \\
\hline
\end{tabular}

determined by behavioural responses to small-scale patches of microhabitat and to different pattern of recruitment.

Due to the seasonality of Mediterranean shallow water communities (e.g., Boero 1994), with fluctuations in the presence and abundance of some species, the taxa identified as important could be less important in other seasons than late spring, when the survey was carried out. The available data on species composition are, however, assumed to reflect a set of environmental conditions that remain constant within a range of seasonal fluctuations.

Species richness differed among sectors, but only 6 taxa were important for sector differentiation. In this study, 4 taxa (Calpensia nobilis, filamentous brown algae, Halimeda tuna, Peyssonellia squamaria) had cover patterns that did not differ significantly in all sectors, their role of important species becoming evident only when considering their relative contribution to community structure. Only 1 taxon (encrusting calcified red algae) differentiated some sectors due to differences of cover, and another one (Schizoporella longirostris) by being absent in some sectors.

The a priori identification of important species is difficult and can usually be done only after the analysis of assemblage structure (Paine 1974, Underwood \& Chapman 1998a).

However, the extraction of data on assemblage structure requires, besides quantitative estimates, taxonomic expertise sufficient to recognise conspicuous organisms underwater (Hiscock 1987), leading to species lists. This taxonomic effort in the field is compensated by no further identification work in the laboratory, apart from the examination of some voucher specimens in the case of difficult species. Obviously, such species lists cannot be compared with those obtained by careful laboratory examination of destructive samples. However, more than 100 species recorded with such a simple and low-cost sampling effort can be considered quite a high number, sufficient to provide a quick and rough estimate of biodiversity over a large geographic area. Cryptic species and epiphytes are obviously lacking, but, on the other hand, many thin encrusting species, easily recognised and quantified visually, are difficult to collect efficiently by scraping the rock (Morri et al. 1999).

The multivariate approach showed less dissimilarity among sites within each sector than the average dissimilarity between each sector and all the remaining ones. However, sites within sectors were considerably different from each other, in spite of having been chosen at random to represent, in the same habitat, an assemblage that is supposed to be the same within each sector. This is in agreement with the high variability at site level recorded at other locations by Archambault \& Bourget (1996) and Underwood \& Chapman (1996, 1998a). As a consequence, replicate samples at different spatial scales are essential in any attempt to compare stretches of coast (Hurlbert 1984, Underwood \& Denley 1984). A well-structured hierarchical design of sampling allows simultaneous assessment of pattern at multiple, overlapping scales (Underwood \& Chapman 1998a).

On subtidal hard substrates, small-scale variability is commonly associated with developing assemblages (Glasby 1998), which seems consistent with the idea that communities in these sites consisted of patches at different developmental stages. In the present study a 

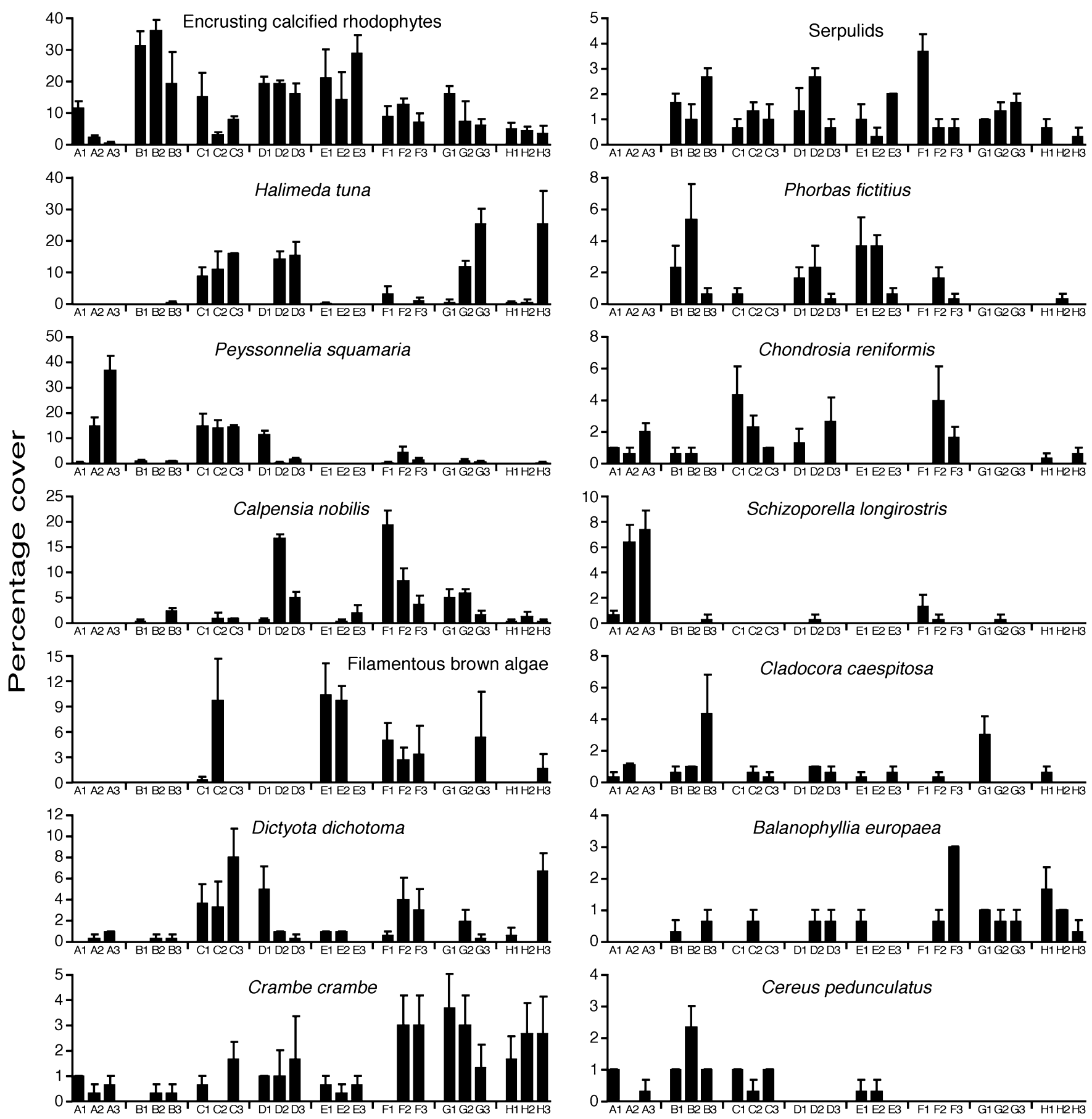

Fig. 7. Spatial distribution of percentage cover (mean $\pm \mathrm{SE}, \mathrm{n}=3$ ) of taxa identified as important (see Table 4) in contributing to similarity within sites and/or dissimilarity among sectors

considerable variability among quadrats (expressed as the average value of similarity) was observed at most sites. The distribution pattern of assemblage similarity within sites was not significantly different among sectors, indicating that patchiness was homogeneously distributed throughout the whole region.
It is obviously not possible to explain all the ecological mechanisms accounting for the observed smallscale patchiness. Such processes include variation in settlement and recruitment, biotic interactions, and heterogeneity in the physical features of the habitat. It is, however, likely that disturbance contributes to cre- 


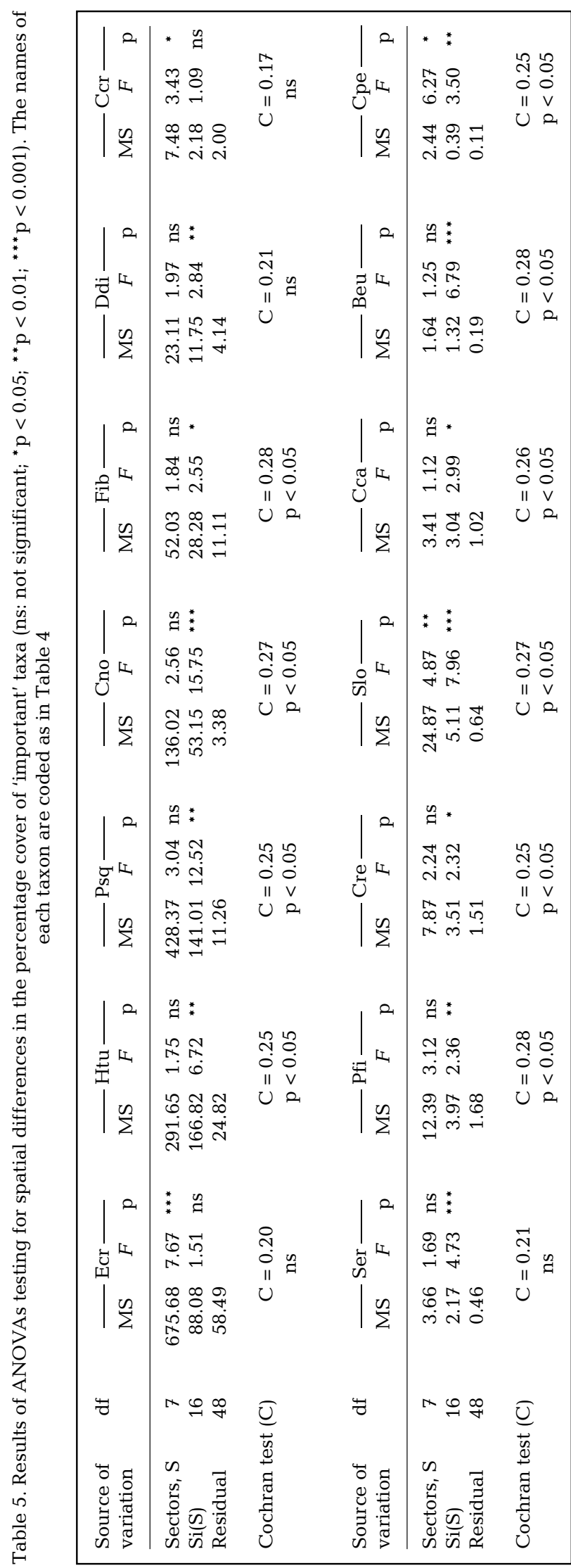

ate patchiness at a small scale. Caswell \& Cohen (1991) hypothesised that disturbance induces higher variability in communities. Warwick \& Clarke (1993) recorded increased variability among replicate samples from several different marine communities exposed to distinct disturbances, thus providing support to the hypothesis and suggesting it may represent a general rule (but see also Chapman et al. 1995 for different findings). In the present case, the relationship between small-scale variability of community structure and damage caused by date mussel fisheries resulted in a curve (Fig. 6) similar to the predicted relationship between diversity and disturbance from the intermediate disturbance hypothesis (Connell 1978). Both sites with no disturbance and highly disturbed ones, in fact, were characterised by a lower level of 'patchiness' than sites with an intermediate level of disturbance. Under conditions of no disturbance, variability of the assemblage among replicate quadrats reflects a natural homogeneity of epibenthic assemblages at a small scale. When disturbance is very high, damage is uniformly distributed, so that all replicate quadrats represent a homogeneously degraded area. Community structure was more variable, at a small scale, when disturbance was intermediate (with $D_{\text {w }}$ values comprised between 0.2 and 0.6). Date mussel fisheries, in this case, produce a mosaic of different community structures, leading to patchiness. At intermediate levels of disturbance, variability might be due to similar damage but of different age (replicate quadrats represented assemblages at different stages of recolonisation) or to the presence of damaged patches of similar age but of different area. As a consequence, also for subtidal epibenthic assemblages (at least at the considered depth, coinciding with the range of action of date mussel fishermen), intermediate levels of disturbance are effective in increasing variability at a small scale.

Our results, then, link Connell's (1978) hypothesis to the model of Warwick \& Clarke (1993). It is reasonable to predict that under conditions of very high disturbance even the variability of the benthic communities analysed by Warwick \& Clarke (1993) would have been very low, due to the almost complete eradication of living forms. This, in fact, was the case for the complete desertification of the Apulian subtidal rocky substrates due to the high impact of date mussel fisheries.

Human impact on target species and/or benthic communities has been widely studied (Moreno et al. 1984, Duran \& Castilla 1989, McClanahan 1989, Castilla 1999, Lasiak 1999). As stressed in the introduction, however, no other form of human predation has a comparable impact to that of date mussel fisheries in terms of habitat destruction. Fanelli et al. (1994) showed that the damage due to date mussel fisheries was spreading from overexploited areas to underexploited ones. Five 
years after those studies, date mussel fisheries did not show any sign of diminution in the whole considered area, in particular in Sector H, where disturbance levels were extremely high. During the 1997 survey, in spite of legislation prohibiting date mussel fisheries, we saw fishermen in action at 3 sites.

Disturbance acting at such a wide scale on the relative abundance of habitat types might have a strong impact on biodiversity. Danielson (1991) remarked that, even when the relative abundance of habitats does not change, variations in their spatial distribution could alter species interactions.

Strong action against this devastating form of human predation is urgently needed, especially aimed to convince consumers that the demand for date mussels is ecologically incorrect. The recent institution of Marine Protected Areas along the coast of Apulia will hopefully lead to habitat restoration and to the perception of the value of environmental integrity.

Acknowledgements. This research was funded by the National Research Council (PRISMA II project), the Amministrazione Provinciale di Lecce (Biodiversità and Porto Cesareo projects), the Regione Puglia (INTERREG Greece-Italy project), MURST (COFIN project). M. C. Buia, L. Della Tommasa, F. Denitto, L. Esposito, A. Giangrande, M. P. Miglietta, S. Piraino and F. Rubino provided invaluable assistance during field work. G. Corriero, C. Longo and A. Petrocelli helped in identifying dubious specimens of sponges and algae. A. J. Underwood, M. G. Chapman, L. Benedetti-Cecchi and the participants of the course 'Design and Analysis of Biological Experiments' (Lecce, May 1999) helped with numerous (and deep) discussions. F. Micheli and R. Coleman kindly revised earlier drafts of the manuscript.

\section{LITERATURE CITED}

Airoldi L (1998) Roles of disturbance, sediment stress, and substratum retention on spatial dominance in algal turf. Ecology 79:2759-2770

Archambault P, Bourget E (1996) Scales of coastal heterogeneity and benthic intertidal species richness, diversity and abundance. Mar Ecol Prog Ser 136:111-121

Barry JP, Dayton PK (1991) Physical heterogeneity and the organization of marine communities. In: Kolasa J, Pickett STA (eds) Ecological heterogeneity. Springer Verlag, New York, p 270-320

Bedulli D, Bianchi CN, Zurlini G, Morri C (1986) Caratterizzazione biocenotica e strutturale del macrobenthos delle coste pugliesi. In: Viel M, Zurlini G (eds) Indagine ambientale del sistema marino costiero della regione Puglia. ENEA, Roma, p 193-202

Benedetti-Cecchi L, Menconi M, Cinelli F (1999) Pre-emption of the substratum and the maintenance of spatial pattern on a rocky shore in the northwest Mediterranean. Mar Ecol Prog Ser 181:13-23

Benedetti-Cecchi L, Bulleri F, Cinelli F (2000) The interplay of physical and biological factors in maintaining mid-shore and low-shore assemblages on rocky coasts in the northwest Mediterranean. Oecologia 123:406-417

Boero F (1994) Fluctuations and variations in coastal marine environments. PSZN I: Mar Ecol 15:3-25

Boero F (1999) Macroecology returns. J Evol Biol 12:999-1001

Bray JR, Curtis JT (1957) An ordination of the upland forest communities of Southern Wisconsin. Ecol Monogr 27: 325-349

Brown JH (1995) Macroecology. University of Chicago Press, Chicago

Butler AJ, Chesson PL (1990) Ecology of sessile animals on sublittoral hard substrata: the need to measure variation. Aust J Ecol 15:521-531

Carlile DW, Skalski JR, Batker JE, Thomas JM, Cullinam VI (1989) Determination of ecological scale. Landscape Ecol 2:203-213

Castilla JC (1999) Coastal marine communities: trends and perspectives from human-exclusion experiments. Trends Ecol Evol 14:280-283

Caswell H, Cohen JE (1991) Communities in patchy environments: a model of disturbance, competition, and heterogeneity. In: Kolasa J, Pickett STA (eds) Ecological heterogeneity. Springer-Verlag, New York, p 97-122

Chapman MG (1994) Small-scale patterns of distribution and size-structure of the intertidal littorinid, Littorina unifasciata (Gastropoda: Littorinidae), in New South Wales. Aust J Mar Freshw Res 45:635-642

Chapman MG, Underwood AJ, Skilleter GA (1995) Variability at different spatial scales between a subtidal assemblage exposed to the discharge of sewage and two control assemblages. J Exp Mar Biol Ecol 189:103-122

Clarke KR (1993) Non parametric multivariate analyses of changes in community structure. Aust J Ecol 18:117-143

Cocito S, Bianchi CN, Degl'Innocenti F, Forti S, Morri C, Sgorbini S, Zattera A (1991) Esempio di utilizzo di descrittori ambientali nell'analisi ecologica del paesaggio sommerso marino costiero. In: Farina A (ed) L'ecologia dell'eterogeneità. Zara, Parma, p 65-68

Connell JH (1978) Diversity in tropical rain forests and coral reefs. Science 199:1302-1310

Connell JH, Sousa WP (1983) On the evidence needed to judge ecological stability or persistence. Am Nat 121: 789-824

Connolly SR, Roughgarden J (1999) Theory of marine communities: competition, predation, and recruitment-dependent interaction strength. Ecol Monogr 69:277-296

Cornell HV, Karlson RH (1996) Species richness of reef-building corals determined by local and regional processes. J Anim Ecol 65:233-241

Damiani V, Bianchi CN, Ferretti O, Bedulli D, Morri C, Viel M, Zurlini G (1988) Risultati su una ricerca ecologica sul sistema marino costiero pugliese. Thal Salentina 18:153-169

Danielson BJ (1991) Communities in a landscape: the influence of habitat heterogeneity on the interactions between species. Am Nat 138:1105-1120

Dayton PK, Thrush SF, Agardy TM, Hofman RJ (1995) Environmental effects of marine fishing. Aquat Conserv Mar Freshw Ecosyst 5:205-232

Dethier MN, Graham ES, Cohen S, Tear LM (1993) Visual versus random-point percent cover estimations: 'objective' is not always better. Mar Ecol Prog Ser 96:93-100

Dunson WA, Travis J (1991) The role of abiotic factors in community organization. Am Nat 138:1066-1091

Duran LR, Castilla JC (1989) Variation and persistence of the middle rocky intertidal community of central Chile, with and without harvesting. Mar Biol 103:555-562

Fanelli G, Piraino S, Belmonte G, Geraci S, Boero F (1994) Human predation along Apulian rocky coasts (SE Italy): desertification caused by Lithophaga lithophaga (Mollusca) fisheries. Mar Ecol Prog Ser 110:1-8 
Farina A (1998) Principles and methods in landscape ecology. Chapman and Hall, London

Forman RTT, Godron M (1986) Landscape ecology. Wiley and Sons, New York

Garrabou J, Riera J, Zabala M (1998a) Landscape pattern indices applied to Mediterranean subtidal rocky benthic communities. Landscape Ecol 13:225-247

Garrabou J, Sala E, Arcas A, Zabala M (1998b) The impact of diving on rocky sublittoral communities: a case study of a bryozoan population. Conserv Biol 12:302-312

Glasby TM (1998) Estimating spatial variability in developing assemblages of epibiota on subtidal hard substrata. Mar Freshw Res 49:429-437

Glasby TM (1999) Differences between subtidal epibiota on pier pilings and rocky reefs at marinas in Sydney, Australia. Estuar Coast Mar Sci 48:281-290

Guichard F, Bourget E (1998) Topographic heterogeneity, hydrodynamics, and benthic community structure: a scale-dependent cascade. Mar Ecol Prog Ser 171:59-70

Hall SJ (1999) The effects of fishing on marine ecosystems and communities. Blackwell Science, Oxford

Hewitt JE, Trush SF, Cummings VJ, Turner SJ (1998) The effect of changing sampling scales on our ability to detect effects of large-scale processes on communities. J Exp Mar Biol Ecol 227:251-264

Hiscock K (1987) Subtidal rock and shallow sediments using diving. In: Baker JM, Wolf WJ (eds) Biological surveys of estuarine and coasts. Cambridge University Press, Cambridge, p 198-237

Hughes TP, Baird AH, Dinsdale EA, Moltschaniwskyj NA, Pratchett MS, Tanner JE, Willis BL (1999) Patterns of recruitment and abundance of corals along the Great Barrier Reef. Nature 397:59-63

Hurlbert SJ (1984) Pseudoreplication and the design of ecological field experiments. Ecol Monogr 54:187-211

Kennelly SJ, Underwood AJ (1993) Geographic consistencies of effects of experimental physical disturbance on understorey species in sublittoral kelp forests in central New South Wales. J Exp Mar Biol Ecol 168:35-58

Lasiak T (1999) The putative impact of exploitation on rocky infratidal macrofaunal assemblage: a multiple-area comparison. J Mar Biol Assoc UK 79:23-34

Levin SA (1992) The problem of pattern and scale in ecology. Ecology 73:1943-1967

Maurer BA (1999) Untangling ecological complexity. University of Chicago Press, Chicago

McClanahan TR (1989) Kenyan coral reef-associated gastropod fauna: a comparison between protected and unprotected reefs. Mar Ecol Prog Ser 53:11-20

Moreno CA, Sutherland JP, Jara HF (1984) Man as a predator in the intertidal zone of southern Chile. Oikos 42:155-160

Morri C, Bianchi CN, Cocito S, Peirano A, De Biasi AM, Aliani S, Pansini M, Boyer M, Ferdeghini F, Pestarino M, Dando $P$ (1999) Biodiversity of marine sessile epifauna at an Aegean island subject to hydrothermal activity: Milos, Eastern Mediterranean Sea. Mar Biol 135:729-739

Editorial responsibility: Roger Hughes (Contributing Editor), Bangor, Wales, UK
Naylor E (1995) Marine biology. In: Encyclopaedia Britannica Yearbook 1995. Encyclopaedia Britannica Inc, London, p 212

Paine RT (1974) Intertidal community structure: experimental studies on the relationship between a dominant competitor and its principal predator. Oecologia 15:93-120

Paine RT, Castilla JC, Cancino J (1985) Perturbation and recovery patterns of starfish-dominated assemblages in Chile, New Zealand and Washington State. Am Nat 125: 679-691

Pérès JM (1982) Major benthic assemblages. In: Kinne O (ed) Marine ecology, Vol 5. J Wiley and Sons, London, p 373-508

Peterson DL, Parker VT (eds) (1998) Ecological scale: theory and applications. Columbia University Press, New York

Riedl R (1971) Water movement: animals. In: Kinne O (ed) Marine ecology, Vol 1. J Wiley and Sons, London, p 1123-1156

Roberts DE (1996) Patterns in subtidal marine assemblages associated with a deep-water sewage outfall. Mar Freshw Res 47:1-9

Russo GF, Cicogna F (1992) Il dattero di mare, Lithophaga lithophaga e gli effetti distruttivi della sua pesca sull'ambiente marino costiero: problemi e prospettive. Boll Mus Ist Biol Univ Genova 56/57:165-194

Smith F, Witman JD (1999) Species diversity in subtidal landscapes: maintenance by physical processes and larval recruitment. Ecology 80:51-69

Thompson RC, Wilson BJ, Tobin ML, Hill AS, Hawkins SJ (1996) Biologically generated habitat provision and diversity of rocky shore organisms at a hierarchy of spatial scales. J Exp Mar Biol Ecol 202:73-84

Tilman D, Kareiva P (1997) Spatial ecology: the role of space in population dynamics and interspecific interactions. Princeton University Press, Princeton, NJ

Underwood AJ (1997) Experiments in ecology: their logical design and interpretation using analysis of variances. Cambridge University Press, Cambridge

Underwood AJ, Chapman MG (1996) Scales of spatial patterns of distribution of intertidal invertebrates. Oecologia 107:212-224

Underwood AJ, Chapman MG (1998a) Spatial analyses of intertidal assemblages on sheltered rocky shores. Aust J Ecol 23:138-157

Underwood AJ, Chapman MG (1998b) Variation in algal assemblages on wave-exposed rocky shores in New South Wales. Mar Freshw Res 49:241-254

Underwood AJ, Denley EJ (1984) Paradigms, explanations and generalizations in models for the structure of intertidal communities on rocky shores. In: Strong DR, Simberloff D, Abele G, Thistle AB (eds) Ecological communities: conceptual issues and the evidence. Princeton University Press, Princeton, NJ, p 151-180

Warwick RM, Clarke KR (1993) Increased variability as a symptom of stress in marine communities. J Exp Mar Biol Ecol 172:215-226

Submitted: April 1, 2000; Accepted: November 17, 2000 Proofs received from author(s): February 13, 2001 